可視化倩報 Vol.13 Suppl. No.2（1993年10月）

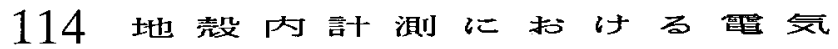
可視化情報 $の$ 高信束面 化

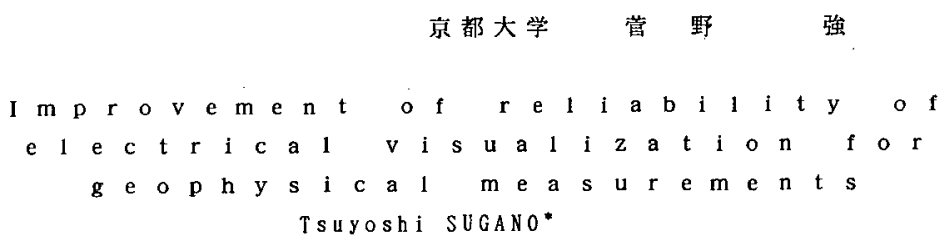

\footnotetext{
Recently in the earth science, geophysical subsurface information can be visualized more easily and detailed. Electrical prospecting methods include the effective subsurface imaging such as resistivity tomography.

In order to improve the accuracy of geophyscal information extraction. pragatic visualization theory and technique have been expected. In this paper. the author try to explain an effective electrical visualization method for subsurface resistivity interpretation. Which includes fundanental and preliminaly/predictive tool and system such as the sensitivity distribution techniques.
}

1.はじめに

地殼内部の可梘化に有効な電気探查法において、比抵抁情報抽出の高精度化とともに、 より信頼性の高い可視化が期待されている。本発表では、その要素技術及び可視化例を報 告する。

さて、過去 40 年間の地球物理学的探圭の情坡起理の有用性の展開では、ここ 25 年間 は、とくに計算機技術の飛躍的進展が大きく寄与していることは今更言うまでもない。計 算機と地球物理学的アクティビティとが石油と政治以上の深い関わりがあると言われるの もうなずける。(い今後のその展望についての新しい課題は、1) 地下構造や地質の解釈 に果たす物理探查の役割で、 3 次元 ( 3 D ) 問題がまず挙げられる。現実には、1次元 ( 1 D D ) インバージョンを綿密に施すか、可能な䉓国で 2 次元（２Ｄ）インバージョンさ らには 3 D 処理をまかなっている。2) 定性的な地下内部推測でなく、例えば、龟裂の方 向の決定やその密度、分布及び広がりの精密な計測ができるかどうか。3）計算機能力の 向上はさることながら、やはり、経済性からの現実的な解析アルゴリスムの検討。4〉計 算機可視化が新しいッールとして不可欠となっている現在、地下の内部情報を計算機で可 視化することが普通で、ょり現実的な画像を提供しつつおる。

ここでは、極めて基礎的な問題で、電気的に地下を可視化するにあたり、地表面や地下 内部に電榀を設置した場合に探查対象物の応答として、龟裂や構造の方向性がどのような 影幚 (効果) をもたらすか、また、複合的な感度情報の利用、などについてーつの検討結 果を報告する。すなわ方、電気探查法の感度解析を例に、水平及び垂直構造異方性と地表 電極配列及び立体電極配列探查特性、そして地下構造探查の一つの可視化手法である比抵 抗トモグラフィに扰ける感度合成の検討について説明する。

\section{2. 地表電極配列法による地下構造探查とその感度解析}

一水平䉓界と双極子電界における異方性感度解析一

まず、電気探查に基本的な水平電界利用の方式について、つきに、双極子電界利用の方 式について、地下構造に買方性があった場合について考察する。

* Faculty of Engineering, Kyoto University, Kyoto-shi. 606-01, Japan 

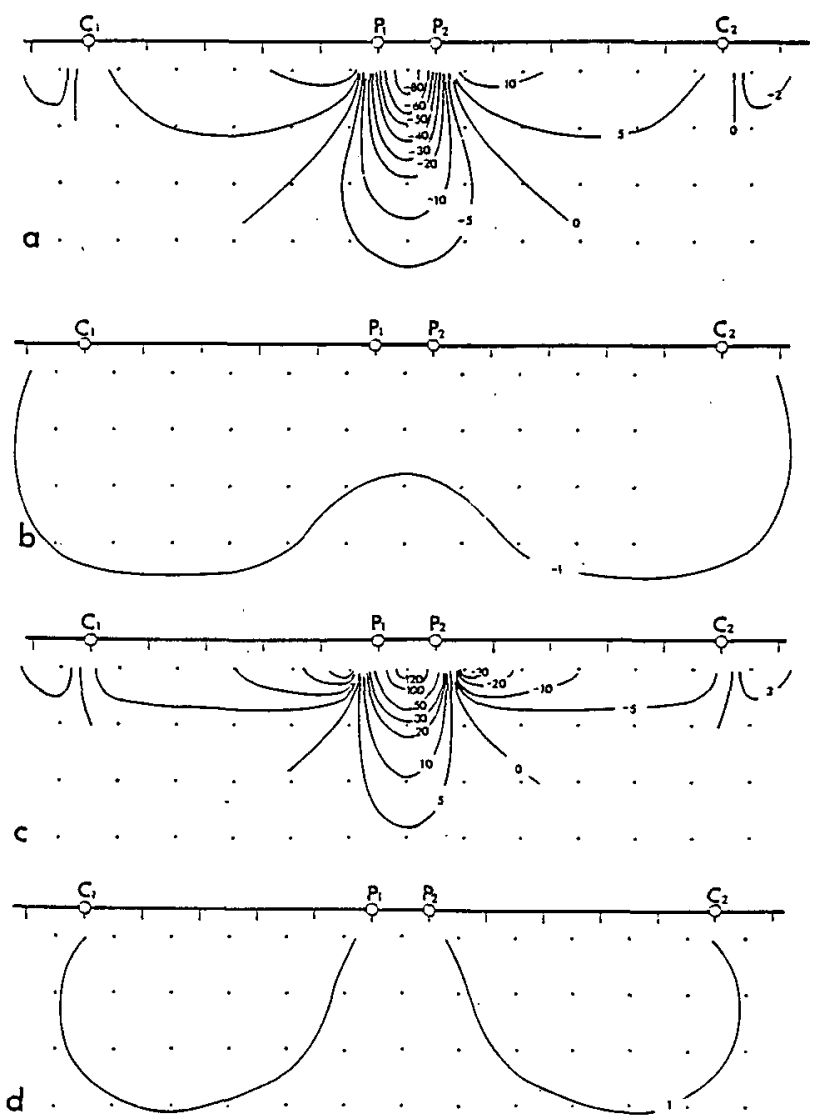

图 1 Schlumberger法曺配题の感度分布
(a) $o_{x} / \rho_{0}=0, o_{y} / o_{0}=1$
(b) $\rho_{x} / D_{0}=1, \rho_{y} / D_{0}=0$
(c) $\rho_{x} / \rho_{0}=\infty, \rho_{y} / \rho_{0}=1$
(d) $o_{x} / \rho_{0}=1, \rho_{y} / \rho_{0}=\infty$
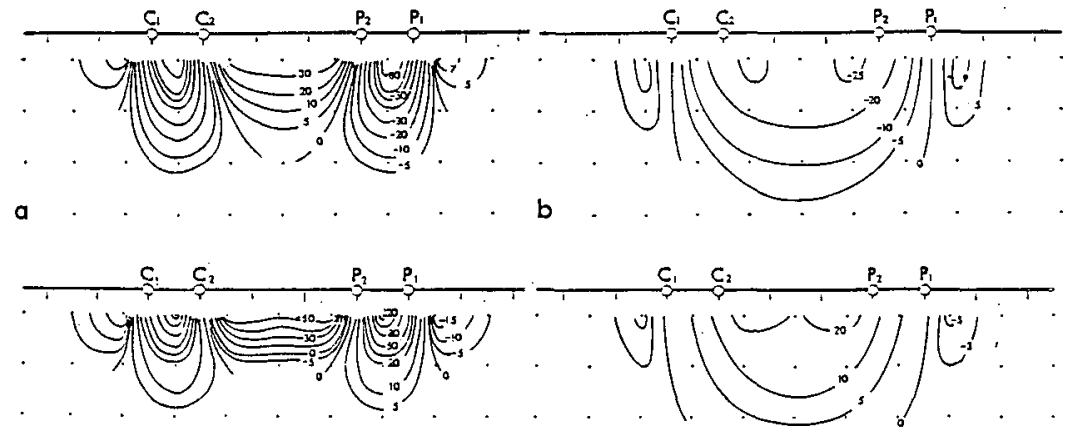

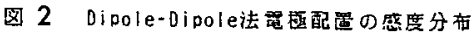
(a) $\rho_{x} / \rho_{0}=0, \rho_{y} / \rho_{0}=1$
(b) $\rho_{x} / D_{0}=1, D_{y} / D_{0}=0$
(c) $\rho_{x} / \rho_{0}=\infty, \rho_{y} / \rho_{0}=1$
(d) $\rho_{x} / \rho_{0}=1, \rho_{y} / \rho_{0}=\infty$ 


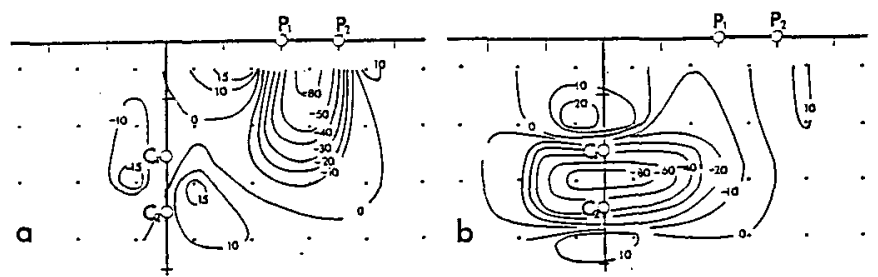

图 3 C C (地下重宜) P P (地成)立体電配置の感度分布
(a) $\rho_{x} / \rho_{0}=0, \rho_{y} / D_{0}=1$
(b) $\rho_{x} / \rho_{0}=1, \rho_{,} / 0_{0}=0$

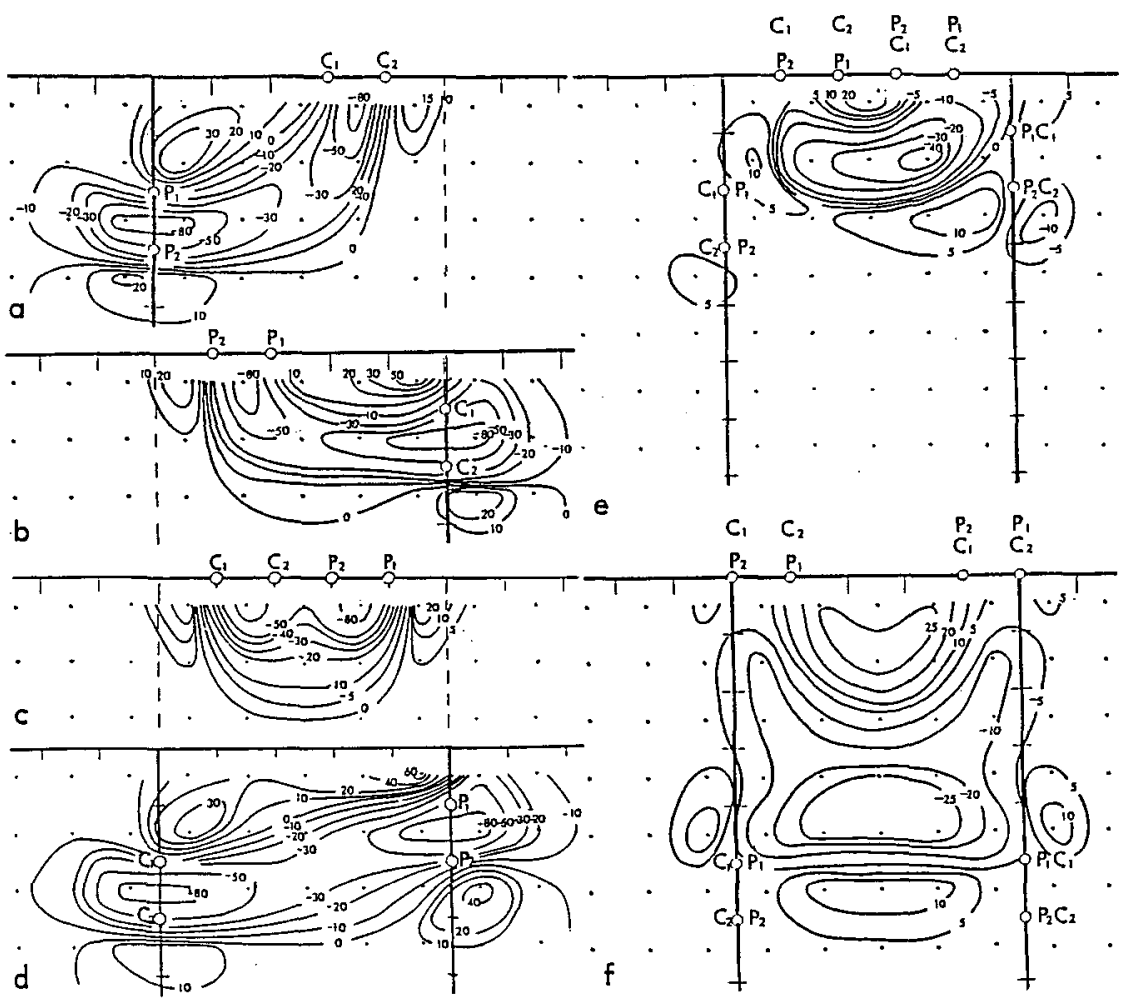

图 4 比抵抗卜モグラフィ電亟配列の感度分布の合成による挨討
(a) $S_{x \rightarrow 0}, \sin t$
(b) $S_{k}, 001 \sin 21$
(c) $S_{x \rightarrow 0-D(n=1)}$
(d) $S_{k}, 00$ (hth
(e) $S_{k}$.0010 (1)
(f) $S_{k}, 00(0(2))$ 
図 1 は、Schlumberger電楥配置と言われるるので概的水平電界を形成する地表電極配列 法の一種である。水平方向に導電性の高い構造や水平方向に䉓流の流れが遮られる構造で

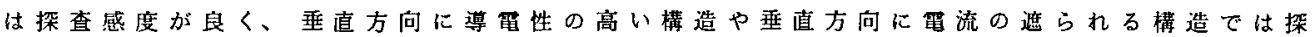
查感度があまり良くないことが分かる。

図2 牥、Dipole-Dipole電極配置と言われるすので、いわゆる双極子電界を形成するむの である。水平方向に冠䉓性の高い構造や水平方向に電流の流れが遮られる構造ては探查感 度汃分離してま亡まりがないが、垂直方向に導電性の高い樌造や垂直方向に電流の遮られ る構造では探查感度が電極系の中央部にまとまる傾向を示していることが分かる。

\section{3. 立体電極配列法にょる地下構造探查とその解析}

一地表孔間方式に拈什る異方性感度解析一

地下内部を挆るのに、地表からのみならずボーリング孔やトンネルなどの観測条件を 利用して探查する立体電極配列法がある。

図 3 は、C C (地下内部) P P (地表面) 方式で、Hole-to-surface電極配置と言われる あのである。（a）図は、水平方向に導電性の高い構造の場合で探查感度が地表電極側に まとまっているのに対し、（b）図は、垂直方向に導電性の高い構造の場合で、地下内部 電極側に探䍒感度がまとまっている。このように地下粠造の性質と探查感度分布特性は密 接な関係にあり、地下情報の可視化及びその結果解积にあたりその要素技術の梌討が十分 にされるべきである。

\section{4. 感度合成法による電気的地下可視化支嗳要素の信頼性向上}

一立体電極㱜列法における感度合成一

色々な電極配置を用いて、電気的な地下情報を抽出するにおたり、より効果的な感度合 成からの画像形成が望ましい。

図4 は、4種類の立体電極配置の感度解析をそれぞれ行ったあと、観测バ夕一ンを合理 的に予測設計するに感度合成を検討した結果で、地下浅部の情報抽出の場合と深部情報抽 出の場合である。感度合成法による電気的地下可視化支授要素の信賴性问上が図られる一 つの新しい手法と考えられる。

なお、此抵抗法の成立しない場合の検討については、一般的な見掛比抵抗を求める電気 探查法を越えて、新しく差動感度分布法が考元られるが、その有効性については、まず、 基礎的な例題の十二分の検討が必要である。その要点研究の成果は、徉来の比抵抗法によ る地下情報の画像化の信頼性向上に役立つと思われる。

\section{5. むすび}

ここでは、地殻内部の可視化に有効な電気探查法において、此抵抗情報抽出の高精度化 とともに、より信頼性の高い可視化が期待されている現状に鑑み、極めてプリミティブな 例題であるが、電気探查法の感度解析を例に、水平及び垂直構造異方性上地表電極配列及 び立体電極配列探查特性、そして地下構造探查の一つの可視化手法である比抵抗卜モグう フィにおける感度合成の検討、及び比抵抗法が成立しない場合の可視化についても触れた。

一般的には、色々な要素技術の検討をはじわ統合的な考察、そして現地応用例における 問題点の解決をふまえた、よりブラグマティックな電気的地下内部可視化の研究開発が進 められる。(2)

\section{参考文献}

(1) Savit, C. H. : Geophysics and Computers-A Look to the Future, Geophysics. The Leading Edge of Exploration. Vol.9, No.3(1990), 21-23.

(2) Sven-Erik Hjelt:Pragmatic Inversion of Geophysical Data, Lecture Notes in Earth Sciences, Springer-Verlag Berlin heidelberg(1992). 